\title{
Simultaneous in situ genotyping and phenotyping of human papillomavirus cervical lesions: Comparative sensitivity and specificity
}

\author{
A K Graham, C S Herrington, J O'D McGee
}

\begin{abstract}
The sensitivity and specificity of immunocytochemistry were compared with those of non-isotopic in situ hybridisation (NISH) for the direct detection of human papillomaviruses in biopsy specimens. Four monoclonal antibodies raised to the capsid protein of HPV16 were less specific than NISH: all four reacted with lesions containing HPV33, and HPV18. Absolute discrimination of HPV types, therefore, was not possible with the monoclonal antibodies used in this study. The relative sensitivities of these antibodies were also lower than NISH. Sequential immunocytochemistry and NISH on the same section showed that $2 \cdot 9-13.0$ times as many cells were positive by NISH than by immunocytochemistry using the most sensitive monoclonal antibody.

These data indicate that NISH has higher diagnostic specificity and sensitivity than immunocytochemistry using monoclonal antibodies to the HPV16 capsid protein.
\end{abstract}

Human papillomaviruses (HPV) are associated with lesions of squamous epithelia. ${ }^{1}$ The isolation and characterisation of HPV DNA has allowed them to be classified into over 50 subtypes based on nucleic acid sequence. ${ }^{2}$ Pathological lesions from different anatomical sites and of different histological patterns are associated with different viral subtypes. $^{23}$ In particular, anogenital lesions are associated with types $6,11,16,18,31,33$, 35 and others. ${ }^{3}$ Within this group HPV types segregate according to the histopathological features, with benign and mildly dysplastic lesions associated with HPV6 and 11, and severe dysplasia and invasive carcinoma associated with $16,18,31,33$, and $35 .^{24}$ The detection and precise typing of HPV types is therefore important in the study of the natural history, epidemiology, and possible oncogenic potential of HPV infection.

Papillomaviruses can be detected in clinical samples in a variety of ways. These depend on being able to show the components of the virus within cells and tissues and therefore entail the detection of either protein or nucleic acid. Viral proteins can be visualised by immunocytochemical techniques and these have been performed with both polyclonal ${ }^{5-7}$ and monoclonal antibodies. ${ }^{8}$ Many viral proteins to which antibodies are directed, however, are expressed in a cycle dependent manner and their demonstration depends on synthesis directed by the virus. This requires that the appropriate part of the viral genome is retained within the nucleus and that it being transcribed/translated. Polyclonal antibedies raised to the bovine papillomavirus (BPV) capsid protein have been used to detect HPV types in human biopsy specimens, because they cross react with several human viral subtypes. ${ }^{5-7}$ Using molecular techniques, bacterial fusion proteins can be synthesised and used as immunogens in mice. Monoclonal antibodies to specific viral proteins have therefore been generated with a view to achieving viral specificity. ${ }^{8}$ The use of the HPV16 L1 (or capsid) protein has led to the production of several antibodies of varying specificity. To date, studies of these antibodies by both Western blotting and immunocytochemistry have been confined to lesions infected with HPV2/6/11/16 and $18 .^{8}$ Several of these antibodies seem to be specific for HPV16 in tissue sections, although one (designated 1C6) recognises the HPV18 L1 protein on Western blots. ${ }^{9}$ The latter antibody, however, was not tested on a tissue section infected with HPV 18. ${ }^{9}$ The description of further HPV subtypes associated with premalignant and malignant disease of the cervix, particularly HPV31, 33, and 35, warrants further investigation of these antibodies.

Immunocytochemistry and non-isotopic in situ hybridisation (NISH) have been combined in the analysis of phenotypic and genotypic characteristics of individual lesions infected with Epstein-Barr virus (EBV), ${ }^{10}$ cytomegalovirus (CMV), ${ }^{11-15}$ and HPV..$^{14-16}$ Initially, parallel sections were investigated using both isotopic ${ }^{811}$ and non-isotopic in situ hybridisation, ${ }^{16}$ but more recently $\mathrm{NISH}$ and immunocytochemistry have been combined on the same tissue section. ${ }^{1012-15}$ Polyclonal antibodies to BPV are widely used for the detection of HPV in clinical material ${ }^{5-7}$ and have been combined with in situ hybridisation using genomic ${ }^{1517}$ and oligonucleotide probes to HPV types. ${ }^{17}$ The latter approach, however, is of limited comparative and diagnostic use as only part of the viral genome is detectable with limited sensitivity. Polyclonal antibodies to HPV16 have also been isolated but show considerable cross reactivity with other HPV types, including HPV1, 2, 6, and $11 .^{8}$

In this study we analysed the immuno- 
cytochemical characteristics of four monoclonal antibodies raised to the HPV $16 \mathrm{Ll}$ protein in lesions infected with a variety of HPV subtypes, including HPV31 and 33, to determine their HPV specificity. An additional aim was to compare the sensitivity of immunocytochemistry with that of NISH. To date, monoclonal antibodies to HPV capsid proteins have only been combined on parallel sections with isotopic in situ hybridisation $^{8}$ or non-isotopic in situ hybridisation. ${ }^{16}$ We have developed a technique which combines NISH and immunocytochemistry to produce substrate products in contrasting colours within the same tissue section. This has shown that cells containing HPV genome are more frequently detected than cells producing HPV capsid protein.

\section{Methods}

SLIDE PREPARATION

All biopsy specimens (from 1972-86) were fixed in formalin and embedded in paraffin wax. Sections $(5 \mu \mathrm{m})$ were cut and mounted on to four-well multispot slides (Hendley, Essex) coated with aminopropyltriethoxysilane as previously described..$^{18}$ After overnight incubation at $60^{\circ} \mathrm{C}$ sections were dewaxed following incubation at $75^{\circ} \mathrm{C}$ for 15 minutes by serial immersion in xylene twice (10 minutes each wash), $99 \%$ ethanol twice (10 minutes each wash), tap and then distilled water.

\section{IMMUNOCYTOCHEMISTRY}

Four monoclonal antibodies raised against the L1 protein ${ }^{8}$ were obtained. These have been designated 5A4, 1C6, 3D 1 and $8 C 4{ }^{8}$ Dewaxed sections were incubated with the appropriate antibody diluted 1 in 50 in $50 \mathrm{mM}$ TRIS HCl, $100 \mathrm{mM} \mathrm{NaCl}$ (pH 7.2) (TBS) for $30-60$ minutes at $22^{\circ} \mathrm{C}$. Dilutions lower than 1 in 50 gave unacceptable background. Subsequent detection followed one of two procedures:

1 After washing for five minutes in TBS sections were sequentially incubated in rabbit anti-mouse (Dako, UK) diluted 1 in 50 in TBS, then alkaline phosphatase anti-alkaline phosphatase complex (APAAP) diluted 1 in 50 in TBS. Signal was developed using nitroblue tetrazolium (NBT)/5-bromo-4-chloro-3-indolyl phosphate (BCIP). ${ }^{19}$

2 After washing in TBS sections were sequentially incubated in biotinylated rabbit anti-mouse $\left[\mathrm{F}\left(\mathrm{ab}^{\prime}\right) 2\right.$ fragment] (Dako, UK) diluted 1 in 200 in TBS, then streptavidin peroxidase (Dako, UK) diluted 1 in 100 in TBS containing $5 \%$ non-fat milk. Signal was developed using aminoethylcarbazole (AEC). This was prepared by dissolving $2 \mathrm{mg} \mathrm{AEC} \mathrm{in}$ $1.2 \mathrm{ml}$ dimethylsulphoxide followed by addition to $10 \mathrm{ml}$ sodium acetate buffer ( $\mathrm{pH} \mathrm{5.0)}$ ). $\mathrm{H}_{2} \mathrm{O}_{2}$ was added $(1 \mu \mathrm{l}$ of stock $30 \%(\mathrm{v} / \mathrm{v}))$ immediately before use.

The polyclonal antibody (Dako, UK) was used at a dilution of 1 in 100 in blocking agent TBT followed by mouse anti rabbit immunoglobulins (Dako, UK) diluted 1 in 25 in TBT. Subsequent detection was performed in the same way as that for the monoclonal antibodies.
UNMASKING OF NUCLEIC ACIDS

Before in situ hybridisation sections were incubated in proteinase $\mathrm{K}$ at a concentration of $500 \mu \mathrm{g} / \mathrm{ml}$ (about 20 units/mg protein) in phosphate buffered saline (PBS) for 15 minutes at $37^{\circ} \mathrm{C}$. Slides were washed thoroughly in distilled water followed by $\mathrm{PBS}$ and dried at $75^{\circ} \mathrm{C}$.

NON-ISOTOPIC IN SITU HYBRIDISATION

Probes for HPV types 6, 11, 16, 18, 31, and 33 were labelled with biotin by nick translation, as described previously. ${ }^{20}$ Aliquots of hybridisation $\operatorname{mix}(9 \mu \mathrm{l})$ containing $10-20 \mathrm{ng}$ of the appropriate biotinylated probe were added to each well on multispot slides, covered with a glass coverslip (Chance, UK), and the slides placed in a moist Terasaki plate. Hybridisation mix consisted of $50 \%$ formamide, $5 \%$ dextran sulphate (BDH, UK), $2 \times \mathrm{SSC}$, and $0.05 \mathrm{~mol} / 1 \mathrm{TRIS}-\mathrm{HCl}(\mathrm{pH} 7.3) ; 1 \times \mathrm{SSC}=$ $0.15 \mathrm{~mol} / \mathrm{l}$ sodium chloride, $0.015 \mathrm{~mol} / 1$ sodium citrate. Sections and probes were simultaneously denatured at $95^{\circ} \mathrm{C}$ for $15 \mathrm{~min}$ utes on a solid stainless steel plate in a hot air oven and then hybridised at $42^{\circ} \mathrm{C}$ for two hours.

DETECTION OF HYBRIDISATION SIGNAL

Preliminary experiments were carried out under high stringency conditions to ensure that the biopsy specimens contained only one HPV type.

Slides were washed in three changes of $4 \times \mathrm{SSC}$ at $22^{\circ} \mathrm{C}$ (five minutes each change) They were then soaked in blocking agent TBT $(0.05 \mathrm{~mol} / 1 \mathrm{TRIS}-\mathrm{HCl}, 0.10 \mathrm{~mol} / 1 \mathrm{NaCl}(\mathrm{pH}$ $7 \cdot 2$ ) containing $3 \%$ bovine serum albumin and $0.05 \%$ Triton $100(\mathrm{v} / \mathrm{v}))$ at $22^{\circ} \mathrm{C}$ for 10 minutes. Probe hybridisation was detected using either streptavidin peroxidase or APAAP, as described for immunocytochemistry, with monoclonal anti-biotin, diluted 1 in 50 in TBT as the primary antibody.

COMBINED NISH AND IMMUNOCYTOCHEMISTRY Immunocytochemistry and NISH were performed sequentially according to the above methods. Development of antibody staining using the APAAP method was followed by NISH using the peroxidase-AEC procedure and vice versa. Unmasking was performed before NISH, irrespective of the order in which immunocytochemistry and NISH were carried out.

\section{QUANTITATION OF STAINING}

After combined NISH and immunocytochemistry the total number of positive cells (red or blue) and those positive by immunocytochemistry (blue) were counted by three independent observers. The positivity was expressed as the ratio of immunocytochemistry and NISH positive cells to immunocytochemistry positive cells and represents the ratio of cells containing viral genome to those containing capsid protein.

\section{Results}

COMBINED IMMUNOCYTOCHEMISTRY AND NISH Using 5A4 and the APAAP detection system 


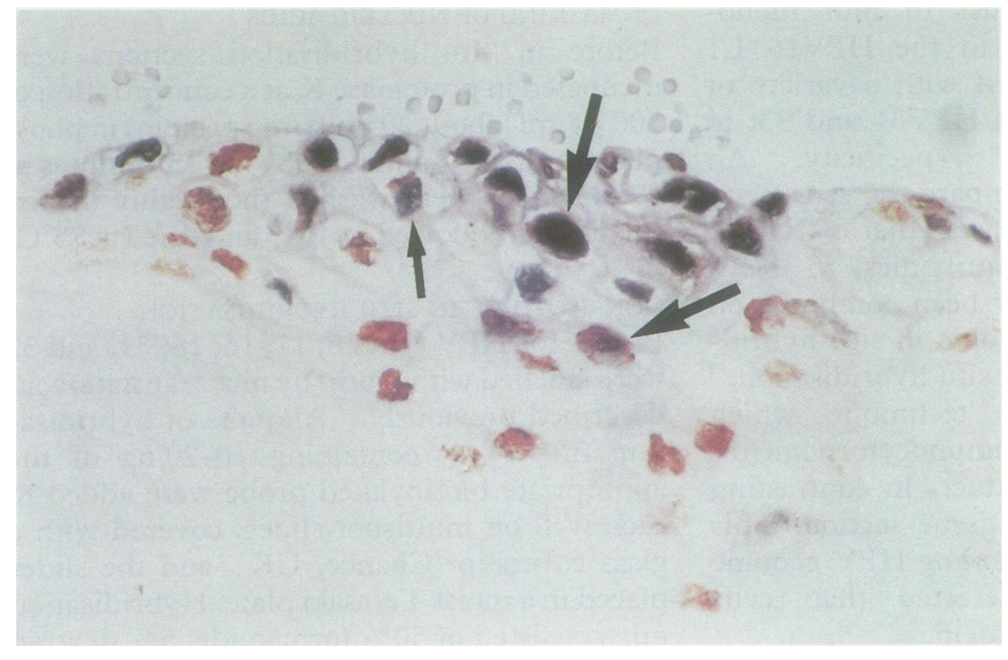

Figure 1 Cervical lesion infected with HPV18, histologically CIN1 with wart virus infection. Combined immunocytochemistry using antibody 1C6, developed as blue/black using NBT/BCIP and NISH, developed as red using AEC. Some nuclei containing both immunocytochemical and NISH signals (large arrow) and a binucleate cell in which one nucleus contains antigen (and nuclei acid) and the other only nucleic acid can be seen (small arrow).

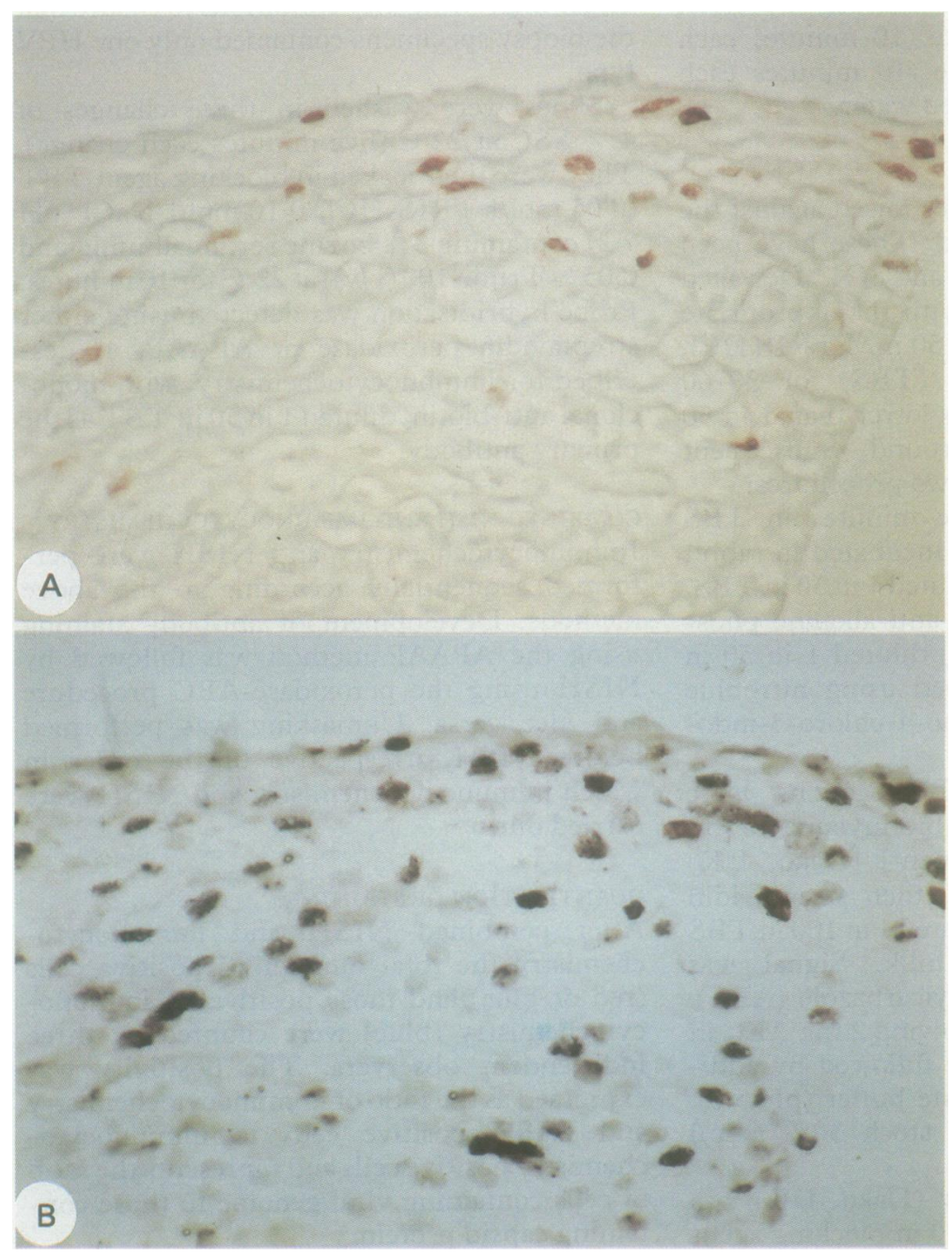

Figure 2 (A) Detection of capsid protein using avidin peroxidase- $A E C$. Protein containing cells are red-brown. ( $B$ ) Combination of immunocytochemistry, developed as red, and NISH, developed as blue, showing that all nuclei containing capsid protein also contain viral nucleic acid.
Table 1 Alternating sequence of immunocytochemistry and NISH affects immunocytochemistry result

\begin{tabular}{ll}
\hline $\begin{array}{l}\text { Combined immuno- } \\
\text { cytochemistry and NISH }\end{array}$ & $\begin{array}{l}\text { Immunocytochemistry } \\
\text { reaction }\end{array}$ \\
\hline $\begin{array}{l}\text { (a) Immunocytochemistry = blue } \\
\text { (b) NISH = red }\end{array}$ & Positive (fig 1) \\
$\begin{array}{l}\text { (a) Immunocytochemistry = red } \\
\text { (b) NISH = blue }\end{array}$ & Positive (fig 2) \\
$\begin{array}{l}\text { (a) NISH = blue } \\
\text { (b) Immunocytochemistry = red }\end{array}$ & Negative \\
$\begin{array}{l}\text { (a) NISH = red } \\
\text { (b) Immunocytochemistry = blue }\end{array}$ & Negative \\
\hline
\end{tabular}

*Procedure (a) was followed by (b).

with NBT/BCIP as substrate on a biopsy specimen infected with HPV16, nuclei containing the viral capsid protein can be clearly seen in the superficial layers of the epithelium (fig 1A). To compare the sensitivity of immunocytochemistry and NISH, procedures were performed sequentially on a consecutive section to that shown in fig $1 \mathrm{~A}$. This showed that NISH detects many more HPV16 positive cells than 5A4 (fig 1B). In the course of working out this sequential protocol, it was found that if in situ hybridisation were performed first, followed by immunocytochemistry, no viral antigen was demonstrable. This is likely to be due to the destruction of the viral antigen by either the temperature required for in situ hybridisation or proteinase $\mathrm{K}$ digestion (table 1). Alternatively, the NISH reaction product may occlude access of antibody to HPV 16 capsid epitopes.

If the colour development scheme is reversed, such that antigen is stained red with peroxidase substrate (AEC) and nucleic acid blue with alkaline phosphatase substrate (NBT/BCIP), all antigen positive cells also contain viral nucleic acid (figs $2 A$ and $B$ ). Thus the sum of blue and red stained cells shown in fig 3 represents those epithelial cells containing viral genome.

\section{RELATIVE SENSITIVITY OF}

\section{IMMUNOCYTOCHEMISTRY AND NISH}

The absolute number of immunocytochemical and NISH positive cells and the NISH: immunocytochemical ratio in four patients are shown in table 2 . The lowest ratio was 2.4 and the highest $32 \cdot 7$. Overall, however, the most sensitive antibody (5A4) gave an NISH: immunocytochemical ratio of 2.9-13.0. There was also a considerable difference in relative sensitivity-that is, NISH/immunocytochemical ratio-in two blocks taken from the same (dysplastic) lesion (table 2, case 1). The total number of antibody and NISH positive cells, together with the NISH:immunocytochemical ratio for three of the patients shown in table 2 are shown in table 3.

In a larger series of 18 cases there were no antibody positive cells in some patients despite the presence of the viral genome, as shown by NISH (table 4). In this series it was also shown that biopsy specimens positive for HPV18 and HPV33 (cases 17 and 18) by NISH also stained with one or more antibodies. 

protein detection in a Nuclei positive with antibody $5 A 4$ can be seen as blue, detected using the $A P A A P-N B T / B C I P$ method. (B) Combination of immunocytochemistry and NISH. Many more nuclei contain viral nucleic acid (red) than capsid protein (blue). Note that both signals are present in
Figure 3 (A) Capsid condyloma acuminatum. some nuclei (arrow).
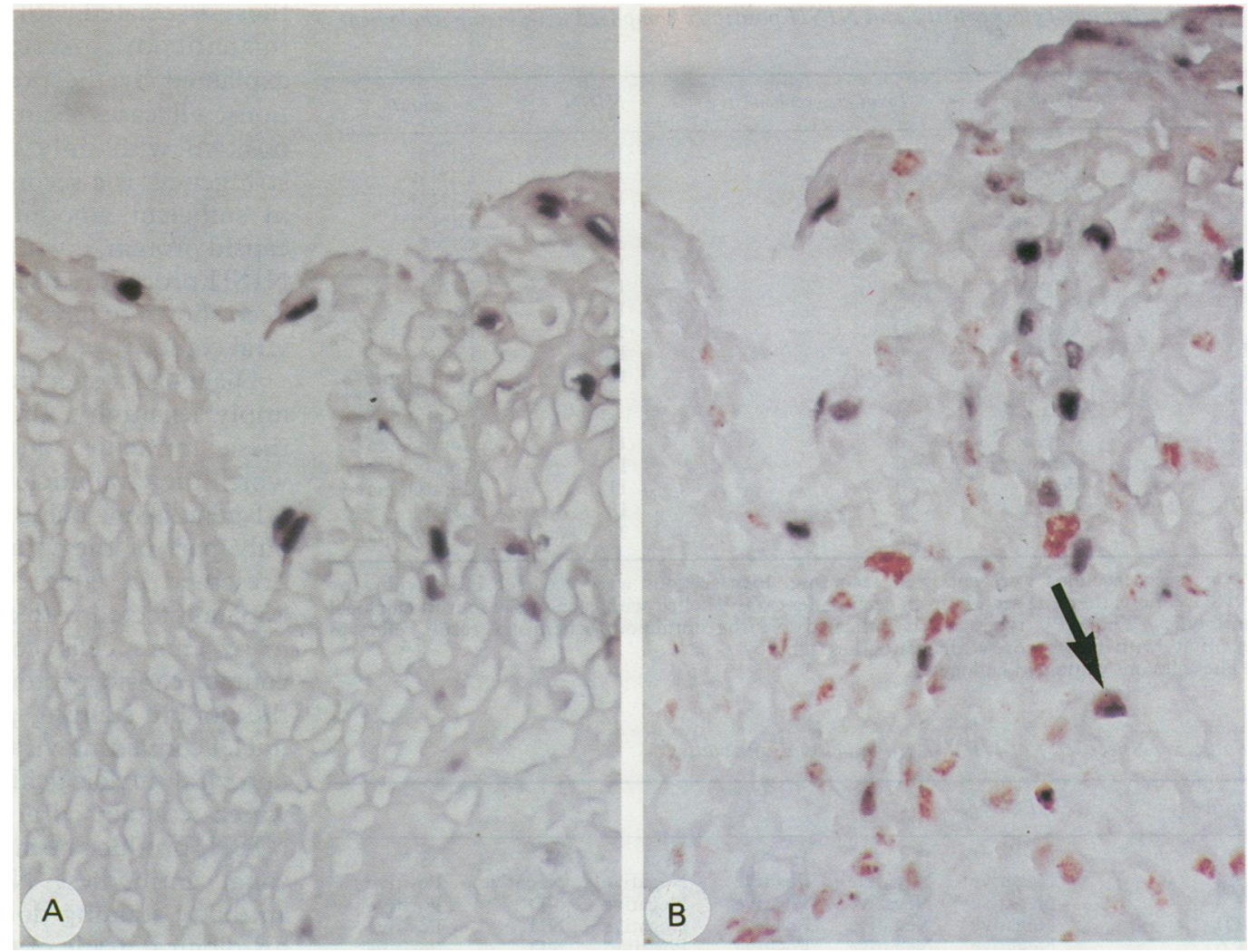

Table 2 Relative sensitivity of immunocytochemistry and NISH*

\begin{tabular}{|c|c|c|c|c|c|c|}
\hline Case No & $H P V$ & Antibody & $\begin{array}{l}\text { Immunocytochemistry } \\
\text { positive }\end{array}$ & NISH positive & Ratio & Diagnosis \\
\hline \multirow[t]{2}{*}{$1+$} & 16 & $\begin{array}{l}5 \mathrm{~A} 4 \\
1 \mathrm{C} 6 \\
3 \mathrm{D} 1 \\
8 \mathrm{C} 4\end{array}$ & $\begin{array}{l}31 \\
24 \\
14 \\
12\end{array}$ & $\begin{array}{l}402 \\
457 \\
422 \\
392\end{array}$ & $\begin{array}{l}13 \cdot 0 \\
19 \cdot 0 \\
30.1 \\
32 \cdot 7\end{array}$ & $\begin{array}{l}\text { CIN3 } \\
\text { +koilocytes }\end{array}$ \\
\hline & 16 & $\begin{array}{l}5 \mathrm{~A} 4 \\
1 \mathrm{C} 6 \\
3 \mathrm{D} 1 \\
8 \mathrm{C} 4\end{array}$ & $\begin{array}{l}23 \\
28 \\
15 \\
18\end{array}$ & $\begin{array}{l}258 \\
158 \\
146 \\
194\end{array}$ & $\begin{array}{r}11.2 \\
5.6 \\
99.7 \\
10.8\end{array}$ & \\
\hline 11 & 16 & $\begin{array}{l}5 \mathrm{~A} 4 \\
1 \mathrm{C} 6 \\
3 \mathrm{D} 1 \\
8 \mathrm{C} 4\end{array}$ & $\begin{array}{r}100 \\
47 \\
66 \\
61\end{array}$ & $\begin{array}{l}536 \\
493 \\
583 \\
512\end{array}$ & $\begin{array}{r}5.4 \\
10.5 \\
8.8 \\
8.4\end{array}$ & Condyloma \\
\hline 17 & 18 & $\begin{array}{l}5 \mathrm{~A} 4 \\
1 \mathrm{C} 6 \\
3 \mathrm{DD} 1 \\
8 \mathrm{C} 4\end{array}$ & $\begin{array}{l}\overline{129} \\
\overline{-}\end{array}$ & $\begin{array}{l}\overline{304} \\
\overline{-}\end{array}$ & $\begin{array}{c}\overline{2} \cdot 4 \\
\overline{-}\end{array}$ & $\begin{array}{l}\text { CIN1 } \\
\text { +koilocytes }\end{array}$ \\
\hline 18 & 33 & $\begin{array}{l}5 \mathrm{~A} 4 \\
\text { 1C6 } \\
\text { 3D1 } \\
9 \mathrm{C} 4\end{array}$ & $\begin{array}{l}284 \\
115 \\
133 \\
190\end{array}$ & $\begin{array}{l}825 \\
754 \\
724 \\
859\end{array}$ & $\begin{array}{l}2.9 \\
6.6 \\
5.4 \\
4.5\end{array}$ & Condyloma \\
\hline
\end{tabular}

*All cells in the entire biopsy specimen from each case were independently counted by two observers (AKG and CSH). The case number refers to data in table 4.

tThe data in case 1 were derived from two separate blocks of the same lesion.

SPECIFICITY OF STAINING WITH MONOCLONAL ANTI-HPV16 L1 AND POLYCLONAL ANTI-BPV This is summarised in table 5 . Although the antibody 5A4 was raised against the $\mathrm{L} 1$ protein of HPV16, it also binds to the capsid protein of HPV33, but not $6,11,18$ or 31 . No lesion was available to investigate HPV 35 . Antibodies 3D1 and 8C4 behaved similarly to 5A4. Antibody 1C6, however, also detected the capsid protein of HPV18 (fig 3). The ability of 1C6, 3D1, and 8C4 to detect the HPV31 capsid protein, however, could not be investigated due to the lack of biopsy specimens infected with HPV31.
Table 3 Absolute and relative sensitivity of immunocytochemistry and NISH*

\begin{tabular}{llll}
\hline Antibody & Immunocytochemistry & NISH & Ratio \\
\hline 5A4 & 438 & 2021 & $4 \cdot 6$ \\
1C6 & 214 & 1862 & $8 \cdot 7$ \\
3D1 & 228 & 1875 & $8 \cdot 2$ \\
8C4 & 281 & 1957 & $7 \cdot 0$ \\
\hline
\end{tabular}

*These data represent the overall immunocytochemistry and NISH positive cells, together with the resultant NISH:immunocytochemistry ratio from cases 1,11 , and 18 shown in table 2 .

\section{Discussion}

The production of monoclonal antibodies to viral proteins is prompted by two main considerations: the investigation of viral protein expression and the detection of viral infection in clinical samples. For the latter aim to be achieved, the viral protein to which the antibody is directed must be synthesised. Thus only cells in which the viral capsid protein is present will produce a positive signal with the antibodies used in this study. The fact that positivity with these antibodies is confined to the superficial layers of the epithelium supports the hypothesis that capsid protein synthesis is a late event in viral replication and occurs immediately before virus shedding. The demonstration of the viral genome, by contrast, does not depend on the stage of replication and, by using probes for the whole genome, nuclei containing only part of the viral nucleic acid can be detected. The data reported here show on single sections that NISH is up to 30 times more sensitive than immunocytochemistry within a given lesion. Overall, the ratio of NISH and immunocytochemistry positive to immunocytochemical positive cells was $6 \cdot 3$ for 
Table 4 Immunocytochemistry and NISH positivity compared with histopathological grade

\begin{tabular}{|c|c|c|c|c|}
\hline Case No & Tissue & Immunocytochemistry & $\cdot \mathrm{NISH}$ & Diagnosis \\
\hline 1 & Cervix & + & 16 & CIN3† \\
\hline 2 & Cervix & + & 16 & CIN3† \\
\hline 3 & Cervix & + & 16 & CIN3† \\
\hline 4 & Cervix & 0 & 16 & CIN $2 \dagger$ \\
\hline 5 & Cervix & 0 & 16 & CIN2 \\
\hline 6 & Cervix & 0 & 16 & CIN3 \\
\hline 7 & Cervix & 0 & 16 & CIN3 \\
\hline 8 & Cervix & 0 & 16 & ISCC \\
\hline 9 & Cervix & 0 & 16 & ISCC \\
\hline 10 & Cervix & 0 & 16 & ISCC \\
\hline 11 & Cervix & + & 16 & Condylomat \\
\hline 12 & Cervix & 0 & 6 & Condyloma $\dagger$ \\
\hline 13 & Anus & 0 & 6 & Condylomat \\
\hline 14 & Cervix & 0 & 11 & Condyloma $†$ \\
\hline 15 & Anus & 0 & 11 & Condylomat \\
\hline 16 & Penis & 0 & 11 & Condylomat \\
\hline 17 & Cervix & + & 18 & CIN1 \\
\hline 18 & Cervix & + & 33 & Condyloma $\dagger$ \\
\hline
\end{tabular}

^Nine serial sections were cut from each case. Five sections were used for HPV typing by NISH. Thereafter, one section from each patient was labelled with each of the four monoclonal antibodies. The HPV types are as indicated and the immunocytochemistry result refers to positivity with one or more of the antibodies (table 5).

$\uparrow$ These lesions contained koilocytes.

Table 5 Specificity of HPV-L1 monoclonal antibodies *

\begin{tabular}{lllllll}
\hline Antibody & HPV type & & & \\
\hline & 6 & 11 & 16 & 18 & 31 & 33 \\
5A4 & Negative & Negative & Positive & Negative & Negative & Positive \\
8C4 & Negative & Negative & Positive & Negative & ND & Positive \\
3D1 & Negative & Negative & Positive & Negative & ND & Positive \\
1C6 & Negative & Negative & Positive & Positive & ND & Positive \\
Polyclonal $\times$ BPV & Positive & Positive & Positive & Positive & ND & Positive \\
\hline
\end{tabular}

${ }^{\star} \mathrm{HPV}$ typing was performed by NISH.

$\mathrm{ND}=$ not done.

$1 \mathrm{C} 6,7 \cdot 0$ for $8 \mathrm{C} 4,8 \cdot 2$ for $3 \mathrm{D} 1$ and $4 \cdot 6$ for $5 \mathrm{~A} 4$. Similarly, lesions in which part or all of the viral genome is present can be detected independent of the production of the capsid protein. Thus both the relative and diagnostic sensitivities of NISH are superior to those of capsid protein immunocytochemistry for HPV detection at the dilutions of antibodies used here. It should be noted that the diagnostic sensitivity of NISH compared with immunocytochemistry depends on the protein detected by immunocytochemistry: the detection of the immediate early and early antigens of cytomegalovirus by immunocytochemistry is of equivalent diagnostic sensitivity to NISH, as assessed by analysis of parallel sections. ${ }^{21}$

The use of monoclonal antibodies to viral gene products has been advocated as a method of achieving diagnostic specificity. ${ }^{8}$ The L1 genes, however, which encode for the capsid proteins of HPV, share up to $88 \%$ of their nucleotide and $92 \%$ of their amino acid sequences. ${ }^{22}$ Thus it is not surprising that hybridomas produced at random may secrete antibodies which cross react with different HPV subtypes. From a diagnostic point of view, an antibody would be of use if it were capable of distinguishing either individual HPV subtypes or groups of viruses associated with diverse clinical behaviour. Thus antibodies 5A4, 3D1, and $8 \mathrm{C4}$ are of limited use as they detect both HPV16 and 33 capsid proteins without cross reacting with HPV 18 or, in the case of 5A4, HPV31. 1C6, however, also cross reacts with the L1 protein of HPV18 and can therefore differentiate the major subtypes associated with malignant progression from those associated with benign lesions. Although this antibody cross reaction could, in theory, be explained by the presence of multiple infections, all cases examined in this study were positive with only one viral probe at high stringency. If a second viral type were present in sufficient amounts to produce detectable capsid protein, it would be detectable using the $\mathrm{NISH}$ procedure used in this study, which has been shown to have a sensitivity of less than 40 viral copies. ${ }^{20}$

Diagnostic specificity does not, however, imply sensitivity. Immunocytochemistry with these antibodies does not detect lesions in which the viral nucleic acid is present, but the L1 gene is not being transcribed, or in which only part of the viral genome remains. Data presented in table 1 showed that in condylomata infected with a variety of viral subtypes many more cells contain nucleic acid than contain capsid protein. Moreover, reversal of the double staining procedure shows that all nuclei containing viral capsid protein also contain viral nucleic acid. Similarly, many lesions which contain viral genome, as shown by $\mathrm{NISH}$, produce no signal with the four monoconal antibodies. Notably, the absence of antibody staining does not correlate with the histological grade of the lesion or the presence of koilocytes. Direct demonstration of viral nucleic acid by in situ hybridisation is therefore both more sensitive and more specific than the detection of viral capsid protein by immunocytochemistry.

The technique described here permits the demonstration of antigen and nucleic acid in the same cells in one tissue section. The greater sensitivity and specificity of NISH compared with capsid protein antibodies shows the greater diagnostic applicability of NISH over immunocytochemistry for HPV infection.

\section{Addendum}

The identification of two lesions infected with HPV 35 as shown by high stringency in situ hybridisation has permitted further analysis of the specificity of the four antibodies used in this study. Capsid protein was detected in both cases by both the polyclonal antiserum to bovine papillomavirus and monoclonal antibody 1C6. 5A4, 3D1, and $8 \mathrm{C} 4$ gave no reaction. These observations show further the wider reactivity of antibody 1 C6 compared with the other three.

This work was supported by grants from the Cancer Research Campaign UK (J O'D McGee)

Wc thank Drs P S Shepherd and D J McCance, Guys Hospital, London for kindly donating the monoclonal antibodies.

1 Syrjanen KJ. Biology of HPV infections and their role in squamous cell carcinogenesis. Med Biol 1987;65:21-39.

2 Wilczynski SP, Bergen S, Walker J, Liao S-Y, Pearlman LF. Human papillomaviruses and cervical cancer: analysis of types. Hum Pathol 1988;19:697-704.

3 Pfister H, Fuchs PG. Papillomaviruses: particles, genome organisation and proteins. In: Syrjanen $K$, Gissmann $L$, Koss LG, eds. Papillomavirus

4 Gross $G$. Lesions of the female external genitalia associated with human papillomaviruses. In: Syrianen $\mathrm{K}$, Gissmann L, Koss LG, eds. Papillomaviruses and

5 Singer A, Wilters J, Walker P, et al. Comparison of 
prevalence of human papillomavirus antigen in biopsies from women with cervical intraepithelial neoplasia. J Clin Pathol 1985;38:855-7.

6 Jenkins D, Tay SK, McCance DJ, Campion MJ, Clarkson PK, Singer A. Histological and immunocytochemical study of cervical intraepithelial neoplasia (CIN) with study of cervical intraepithelial neoplasia (CIN) with 1986;39:1177-80.

7 Banks L, Matlashewski G, Pim D, Churcher M, Roberts C, Crawford L. Expression of human papillomavirus type 6 and type 16 capsid proteins in bacteria and their antigenic characterisation. J Gen Virol 1987;68:3081-9.

8 Patel D, Shepherd PS, Naylor JA, McCance DJ. Reactivities of polyclonal and monoclonal antibodies raised to the major capsid protein of human papilloma virus type 16 . J Gen Virol 1989;70:69-77.

9 Cason J, Patel D, Naylor J, Shepherd PS, Best JM, McCance DJ. Identification of immunogenic regions of the major coat protein of human papillomavirus type 16 that contain type-restricted epitopes. J Gen Virol 1989;70:2973-87.

10 Kornstein MJ, Weber J, Luck JB, Massey GV, Strom S McWilliams NB. Epstein-Barr virus associated lymphoproliferative disorder. Arch Pathol Lab Med 1989; phoproliferat

11 Brigati DJ, Myerson D, Leary JJ, et al. Detection of vira genomes in cultured cells and paraffin-embedded tissue sectons using biotin-labelled hybridisation probes. Virology 1983;126:32-50.

12 Wolber RA, Lloyd RV. Cytomegalovirus detection by nonisotopic in situ DNA hybridisation and viral antigen immunostaining using a two colour technique. Hum Pathol 1988;19:736-41.

13 Roberts WH, Sneddon JM, Waldman J, Stephens RE. Cytomegalovirus infection of gastrointestinal endohelium demonstrated by simultaneous nucleic acid hybridisation and immunohistochemistry. Arch Pathol Lab Med 1989;113:461-4.
14 Van der Loos CM, Volkers HH, Rook R, Van den Berg FM, Houthoff H-J. Simultaneous application of in situ DNA hybridisation and immunohistochemistry on one tissue section. Histochem J 1989;21:279-84.

15 Mullink H, Walboomers JMM, Tadema TM, Jansen DJ, Meijer CJLM. Combined immuno- and nonradioactive hyeider hybridocy influence of fixation, enzyme pretreatment, and choice of chromogen on detection of antigen and

16 Jenson AB, Lim LY, Singer AE. Comparison of human papillomavirus type 1 serotyping by monoclonal antibodies with genotyping by in situ hybridisation of plantar warts. J Cutan Pathol 1989;16:54-9.

17 Cubie HA, Norval M. Detection of human papillomaviruse in paraffin wax sections with biotinylated synthetic oligonucleotide probes and immunogold staining. J Clin Pathol 1989;42:988-91.

18 Burns J, Graham AK, McGee JO'D. Non-isotopic detection of in situ nucleic acid in cervix: an updated protocol. J Clin Pathol 1988;41:897-9.

19 Burns J, Graham AK, Frank C, Fleming KA, Evans MF, McGee JO'D. Detection of low copy human papilloma virus DNA and mRNA in routine paraffin sections of cervix by non-isotopic in situ hybridisation. J Clin Pathol cervix by non-1soto

20 Herrington CS, Burns J, Graham AK, Evans MF, McGee JO'D. Interphase cytogenetics using biotin and digoxigenin labelled probes I: relative sensitivity of both reporters for detection of HPV 16 in CasKi cells. J Clin Patho 1989;42:592-600.

21 Jiwa NM, Raap AK, Van de Rijke FM, et al. Detection of cytomegalovirus antigens and DNA in tissues fixed in formaldehyde. J Clin Pathol 1989;42:749-54.

22 Dartmann K, Schwarz E, Gissmann L, zur Hausen H. The nuclcotide sequence and genome organization of human papilloma virus type 11. Virology 1986;151:124-30.

\section{Eponyms in pathology ...}

von STERNBERG, Karl (1872-1935) was an Austrian pathologist, born and trained in Vienna, who qualified in 1896 . After working as assistant to Paltauf in Vienna he was made professor of pathology there in 1908. He described the characteristic giant cells of Hodgkin's disease in 1898, later described by Dorothy Reed (a pathologist at Johns Hopkins University, Baltimore) in 1906 . He also wrote a paper on "lymphosarcoma-cell" leukaemia, sometimes called Sternberg's leukosarcoma.

GIARD, Alfred (1846-1908) was a Parisian biologist who was a staunch follower of the doctrine of Lamarck. In 1882 he described the genus of flagellate protozoan now called Giardia.
PANETH, Joseph (1857-1890) was an Austrian physiologist, born in Vienna, who held chairs of physiology in Breslau and Vienna. In 1888 he described the secretory cells in the crypts of the small intestinal mucosa which now bear his name.

BETZ, Vladimir Aleksandrovich (18341894) was a Russian anatomist who was professor of anatomy in Kiev from 1868 to 1889 . He described the large pyramidal cells of the motor cortex (Betz cells) in 1874. 